\title{
A Nap sötét oldala: retinopathia solaris esetének multimodális bemutatása
}

\author{
Molnár Adél oh. ${ }^{1}$ - Gombocz Eszter oh. ${ }^{1}$ \\ Nagy Zoltán Zsolt dr. ${ }^{2}$. Schneider Miklós dr. ${ }^{2,3}$ \\ ${ }^{1}$ Semmelweis Egyetem, Általános Orvostudományi Kar, Budapest \\ ${ }^{2}$ Semmelweis Egyetem, Általános Orvostudományi Kar, Szemészeti Klinika, Budapest \\ ${ }^{3}$ Rigshospitalet, Department of Ophthalmology, Glostrup, Dánia
}

\begin{abstract}
A solaris retinopathia a fotoreceptorok és a retina pigmentepitheliumának ultraibolya (UV) fény okozta fotokémiai és termikus károsodása. A behatás következtében a leggyakoribb panaszok között a visuscsökkenés, a homályos látás és a pozitív scotomák szerepelnek. A diagnózis alkotásában az optikai koherencia tomográfia (OCT), a mikroperimetria és a fluoreszcein angiográfia (FLAG) nyújt segítséget. A szerzők egy 18 éves férfi esetét mutatják be, aki prolongált napfény-expozíció után jelentkezett a Semmelweis Egyetem Szemészeti Klinikáján, mindkét szemet érintő centralis scotoma miatt. Az OCT-felvételeken a retina egyes rétegeiben folytonossághiányt és reflexiófokozódást figyeltünk meg, míg mikroperimetriás vizsgálattal a laesióknak megfelelően érzékenységcsökkenés volt tapasztalható. A féléves követés során a jobb retina folytonossághiánya csökkent, míg a bal oldal teljes restitúciót mutatott. A mikroperimetriás lelet az OCT-n látottakkal korrelált. A beteg szubjektív panasza a jobb szemén minimálisra csökkent, mindennapi életét nem korlátozza, a bal szemére megszűnt. A solaris retinopathiának jelenleg specifikus terápiája nincs. A panaszok és az eltérések kedvező esetben 3-6 hónap alatt normalizálódnak, ez felhívja a figyelmet a megfelelő tájékoztatás és a prevenció szerepére.
\end{abstract}

Orv Hetil. 2020; 161(16): 632-636.

Kulcsszavak: solaris retinopathia, solaris retinitis, optikai koherencia tomográfia, fénykárosodás

\section{The dark side of the Sun: multimodal imaging of a solar retinopathy case}

Solar retinopathy is the photochemical and thermic injury of the retinal photoreceptors and the pigment epithelium caused by ultraviolet (UV) radiation. As a consequence, the most common symptoms are visual acuity deterioration, blurred vision and positive scotoma. Optical coherence tomography (OCT), microperimetry and fluorescein angiography (FLA) are helpful in determining the diagnosis. Authors present an 18-year-old male having central scotomas affecting both eyes who presented at the Department of Ophtalmology of Semmelweis University. OCT scans revealed a localised defect and hyperreflectivity of certain retinal layers and microperimetry examination detected decreased retinal sensitivity consistent with the lesions. After a follow-up of 6 months, the defect of the right eye became more subtle and the one on the left disappeared completely. Microperimetry results correlated with OCT findings. Subjective symptoms on the right eye decreased significantly and they do not affect his daily life anymore, symptoms on the left eye discontinued. Currently, no specific therapy exists for solar retinopathy. Symptoms and defects in favourable cases normalise in 3-6 months which highlights the importance of public health education and prevention.

Keywords: solar retinopathy, solar retinitis, optical coherence tomography, sunlight exposure

Molnár A, Gombocz E, Nagy ZZs, Schneider M. [The dark side of the Sun: multimodal imaging of a solar retinopathy case]. Orv Hetil. 2020; 161(16): 632-636.

(Beérkezett: 2019. december 13.; elfogadva: 2020. január 9.)

\section{Rövidítések}

$\mathrm{FAF}=$ fundus-autofluoreszcencia; FLAG $=$ (fluorescein angiography) fluoreszcein angiográfia; LSD = lizergsav-dietilamid; OCT $=($ optical coherence tomography $)$ optikai koherencia to- mográfia; $\mathrm{PCP}=$ fenciklidin; $\mathrm{RPE}=$ retinalis pigmentepithelium; SER = (smooth endoplasmic reticulum) sima felszínú endoplazmatikus retikulum; $\mathrm{UV}=$ (ultraviolet) ultraibolya 
A solaris retinopathia a retina pigmentepitheliumának (RPE) és a fotoreceptorok külső szegmensének nagyrészt fotokémiai, kisebb részben termikus és mechanikus károsodása [1]. A fotokémiai károsodásért a nagy energiájú ultraibolya (UV)-B (UVB)-hullámok és az alacsony energiájú UVA-sugárzás felelősek. Az agresszív UV-sugárzás a szemgolyó hátsó pólusán károsodást okoz, a kórkép tünetei között homályos látás, metamorphopsia, centralis és paracentralis scotomák, homloktáji fejfájás, migrén szerepelnek [2]. A visusromlás általában aszimmetrikus és kétoldali, a látóélesség átlagosan 0,25 és 0,66 (20/80-20/30) között van, a napfény-expozíció idejétől függően. A színlátás és a kontrasztérzékenység jellemzően megtartott marad [1, 2].

A diagnózis felállításában a funduskamera, az optikai koherencia tomográfia (OCT), a mikroperimetriás és a fluoreszcein angiográfiás (FLAG) vizsgálatok nyújthatnak segítséget.

Az OCT az interferometria elvén, infravörös lézersugarak kibocsátása révén nagy felbontású képalkotást eredményez a retina rétegeiről és morfológiai, akár szubklinikus eltéréseiről. A mikroperimetria a macula területén határozza meg a retina érzékenységét. A FLAGvizsgálat során vénás fluoreszcein adását követően vizsgálható a szem hátsó pólusának keringése.

Jelen tanulmányunk célja a solaris retinopathia etiológiájának, lefolyásának bemutatása egy fiatal férfi esetén keresztül.

\section{Esetismertetés}

Egy 18 éves férfi beteg 5 napja fennálló, mindkét szemet érintő látáspanasszal jelentkezett szemészeti vizsgálatra Klinikánkon. Elmondása alapján szemüveg, napszemüveg vagy védőszemüveg nélkül több alkalommal direkt napfénybe nézett 6-7 másodperces intervallumokra, ezt követően 2 órával vette észre, hogy mindkét szemével rosszabbul lát, kétoldali centralis scotomáról számolt be.

A beteg szemészeti és általános anamnézisében nem szerepelt betegség, gyógyszerszedés, káros szenvedélyról nem számolt be.

Legjobb korrigált látóélessége a zavaró scotoma ellenére a jobb és bal szemen egyaránt 1,0 volt. Az elülső szegmens vizsgálatakor kóros eltérést nem találtunk. Pupillatágítást követő szemfenéki vizsgálatakor a jobb szem foveolájában és bal szem foveola melletti területén kis sárgás elszíneződés volt megfigyelhető (1. ábra: $A, B$ ). A beteg szemfenekéról fundusfotó (Nidek AFC-210 Nidek Co. Ltd., Hamagori, Japán), macula-OCT, OCTangiográfia, fundus-autofluoreszcencia (FAF) (Spectralis OCT - Heidelberg Engineering GmbH, Heidelberg, Németország) és mikroperimetriás (MAIA - CenterVue S.p.A, Padova, Olaszország) vizsgálat készült. Az OCTfelvételeken a sárga laesiónak megfelelően a retinalis pigmentepitheliumban nem volt eltérés, az interdigitációs zónában és az ellipszoid zónában azonban folytonossághiányt figyeltünk meg. Az előbbi folytonossághiány terü-
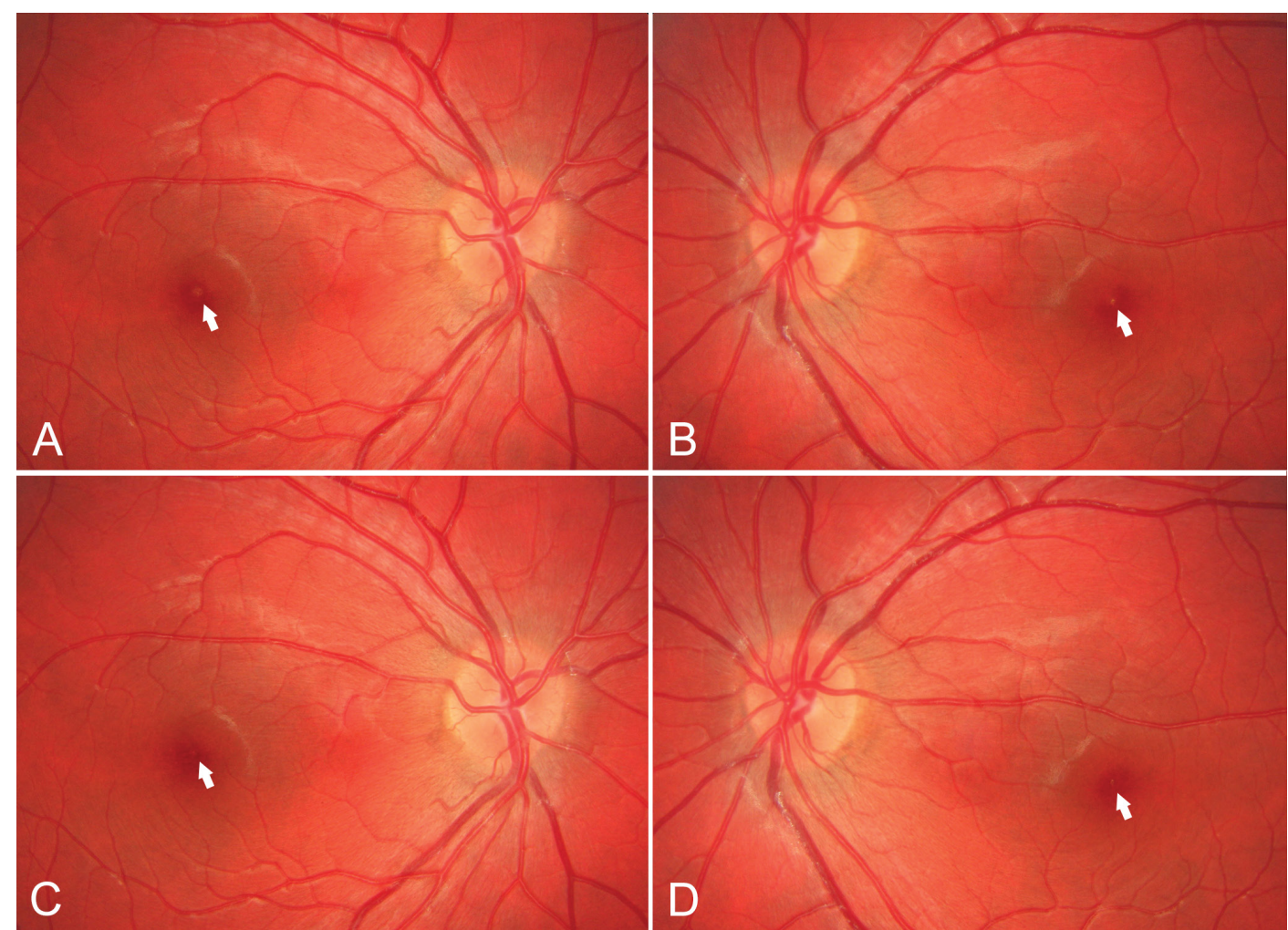

Színes fundusfotók a jobb (A, C) és a bal (B, D) szemről. A jelentkezés napján, 5 napos panaszokkal, a jobb oldali (A) foveolában és a bal oldali (B) foveola melletti területen kis sárgás elszíneződés látható (fehér nyilak), amelyek a három hónapos kontrollra a jobb (C) és a bal (D) oldali foveában alig látható laesióvá (fehér nyilak) fejlődtek vissza 


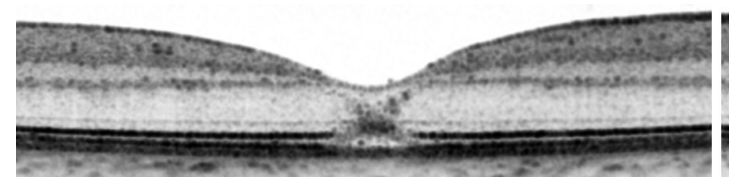

A
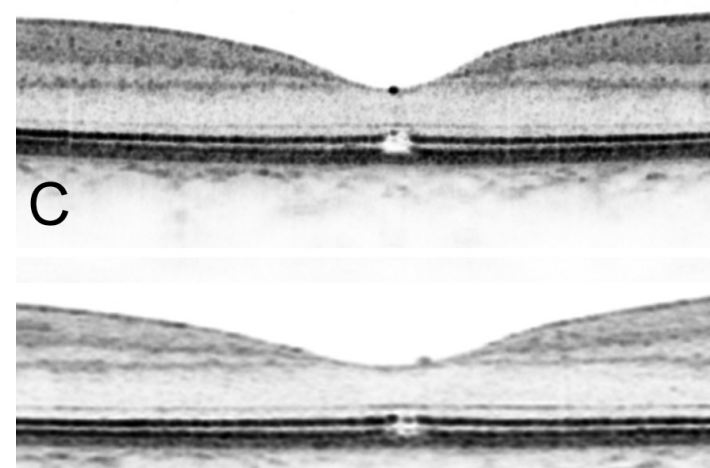

E

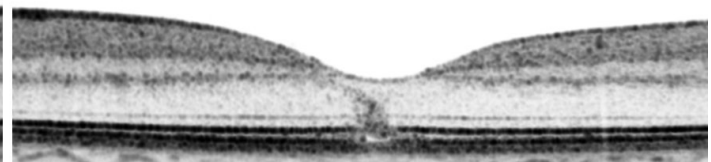

B
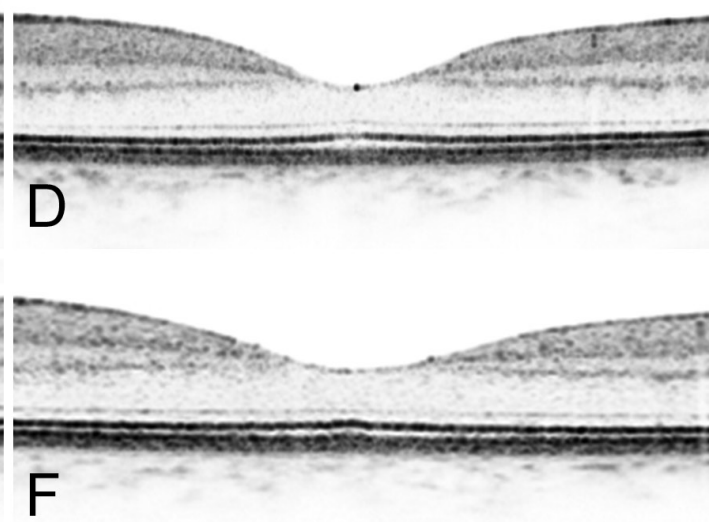

2. ábra

Optikai koherencia tomográfiás (OCT) felvételek a jobb (A, C, E) és a bal (B, D, F) oldali maculáról, a jelentkezés napján (A, B), két hónappal később $(\mathrm{C}, \mathrm{D})$ és a károsodás után hat hónappal $(\mathrm{E}, \mathrm{F})$

letében a fotoreceptor külső szegmentumban reflexiófokozódást láttunk, amely összefüggött a membrana limitans externa szintjében megjelent hiperreflektív anyaggal, illetve ennek a külső magvas rétegbe való $\mathrm{V}$ alakú radiációjával (2. ábra: $A, B$ ). A retina vastagsága normális volt. A mikroperimetriás vizsgálat során mindkét oldalon a laesiókkal megegyező területeken érzékenységcsökkenés (3. ábra: $A, B$ ) volt észlelhető. $\mathrm{Az}$ OCT-angiográfiás és a FAF-vizsgálatnál jelentős eltérés nem volt megfigyelhető.

Az első vizsgálat után a beteg állapotát 6 hónapon keresztül követtük, és a fenti vizsgálatokat a kontrollok során megismételtük.

Az első vizsgálatot követően 10 nappal, a maculaOCT-felvételeken a foveatájon lévő sárgás területek mindkét oldalon rekonvaleszcenciát mutattak. Jobb oldalon az interdigitációs és az ellipszoid zóna integritása nem állt helyre, a hiperreflektív radiáció azonban megszűnt. Bal oldalon a javulás gyorsabb volt, az ellipszoid zóna folytonossága helyreállt, eltűnt a hiperreflektív radiáció, a fotoreceptor külső szegmentumban kisfokú kiszélesedés és egyenetlen reflexió volt megfigyelhető, az interdigitációs zónában a folytonossághiány továbbra is megvolt. Mikroperimetriával mindkét szemben kismértékben javult centralis funkció volt kimutatható.

A károsodást követő 31 . napon az OCT-felvételen a foveolában az interdigitációs és az ellipszoid zónában lévő folytonossághiány a jobb szemen kisebb volt, míg a bal szem esetében az integritás helyreállt, kis egyenetlenség mellett. A mikroperimetriás vizsgálatok ezen ered-
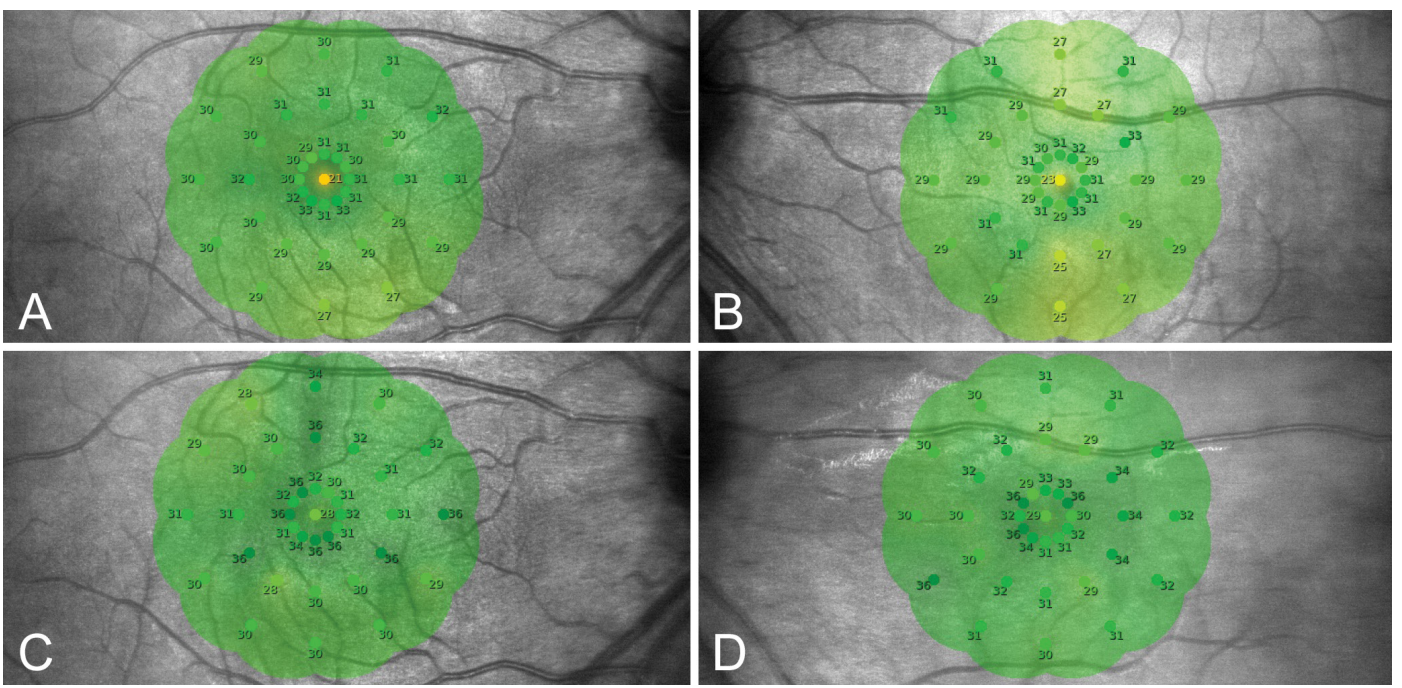

3. ábra

| Microperimetriás vizsgálatok a jobb $(\mathrm{A}, \mathrm{C})$ és a bal $(\mathrm{B}, \mathrm{D})$ szemről a jelentkezés napján $(\mathrm{A}, \mathrm{B})$ és a károsodás után hat hónappal $(\mathrm{C}, \mathrm{D})$ 
ményekkel korreláltak, jobb oldalon csökkent, bal oldalon normális centralis érzékenységet láttunk.

A két hónapos kontroll során a foveolán áthaladó OCT-scanen a jobb oldali interdigitációs és ellipszoid zónában korábban látott folytonossághiány a korábbi kontrollhoz hasonló volt. A bal oldalon a korábbi egyenetlenségek is megszúntek (2. ábra: $C, D$ ).

A szemfenéki képen a sárgás elszíneződés mérete a kontrollok során mindkét oldalon fokozatosan csökkent; három hónappal a panaszok megjelenése után (1. ábra: $C, D)$ alig látható, apró, kerek, sárgás laesio volt megfigyelhető, amely az ezt követő kontrollok alkalmával már nem változott tovább. Az OCT-n a három hónapos kontrollnál a jobb oldali foveatáji interdigitációs és ellipszoid zónában lévő folytonossághiány mérete az előző vizsgálatok során látottakkal közel azonosnak bizonyult. A jobb szemen a mikroperimetriás vizsgálat az elózô kontrollvizsgálathoz hasonló fovealis funkciót mutatott, a juxtafovealis régióhoz képest minimálisan alacsonyabb érzékenység volt megfigyelhető.

$\mathrm{Az}$ utolsó kontrollvizsgálaton, fél évvel a károsodás után, a macula-OCT-n a jobb foveola állapota nem változott (2. ábra: $E$ ), a bal szemen az integritás továbbra is megtartott volt (2. ábra: F). A mikroperimetria során a jobb szemen jó, minimálisan alacsonyabb foveolaris érzékenység (3. ábra: C), míg a bal szemen normális érzékenység volt tapasztalható (3. ábra: $D$ ). A beteg szubjektív panaszai a bal szemén teljes mértékben megszúntek, a jobb szemén minimális scotomáról számolt be, amely nem zavarja, átlagos élethelyzetekben nem tapasztalja, csak akkor veszi észre, ha tudatosan keresi.

\section{Megbeszélés}

A történelemben több híres személynél is megfigyelhetők voltak napfény okozta szemkárosodások, például Szent Pálnál, Galileo Galileinél vagy Petőfi Sándornál $[1,3,4]$. Az első esetleírás a XVII. századból származik, ám a károsodás definitív leírója Rosen volt 1948-ban [5, 6]. A károsodás multifaktoriális, függ az egyén fogékonyságától, az expozíció idejétől és helyétól [2].

Etiológiáját tekintve a solaris retinopathia többnyire napfogyatkozáshoz, napozáshoz, szabadidős programokhoz, hegesztéshez, lézerexpozícióhoz társul, ám hátterében vallási-rituális, pszichiátriai okok (például skizofrénia) következtében hosszabb ideig tartó Napba nézés, kábítószer-abúzushoz (például lizergsav-dietilamid [LSD], fenciklidin [PCP]) társuló ártalom is szerepelhet $[1,4]$. Bizonyos pszichotrop szerek megváltoztatják a környezet percepcióját, a tér- és időélmény eltorzulásához vezetnek. A szerhasználó fokozott figyelmet fordít a fényes tárgyakra, emellett a drog okozta esetleges mydriasis is fokozottabb expozícióhoz vezet.

A fiatalok optikai törőközegei jellemzően transzparensebbek, és lencséjük elsősorban a 315-400 nm közötti, nagyobb hullámhosszúságú, kisebb energiájú UVA-sugárzást abszorbeálja, míg az idősebb lencse a 280-315 nm közti, rövidebb hullámhosszúságú, nagyobb energiájú UVB-sugár elnyelődését akadályozza. Ennek következtében a fiatalabb pácienseknél solaris retinopathia könnyebben alakul ki, ám regenerációs képességük is jobb [2]. Egyes fotoszenzitivizáló gyógyszerek - mint a szulfonamidok, tetraciklinek, fluorokinolonok vagy a pszoralén - szedése szintén növeli a károsodás rizikóját [3]. A védőfaktorok között a cataracta, az erősen pigmentált fundus és az erősebb fénytörési hiba szerepelnek [7].

A panaszok először rendszerint az expozíció után 1-4 órával jelentkeznek, és a legtöbbször 3-6 hónap múlva normalizálódnak, bemutatott esetünkhöz hasonlóan. Az expozíció után körülbelül 24 órával eltúnik a foveareflex, ezt követően 1 hét múlva sárgás laesio jelenik meg a foveában. Ennek helyén 14 nap múlva demarkált, lamelláris elváltozás tapasztalható $[8]$. Az oftalmoszkópos és réslámpával történő vizsgálat során észlelhető elváltozások számos differenciáldiagnosztikai kérdést vethetnek fel, ezért a diagnózisalkotáshoz elengedhetetlen az OCT használata. Az OCT B-scan felvételeken karakterisztikusan a retina pigmentepitheliumától a külső határhártyáig húzódó, négyzet alakú lyukképződés figyelhető meg [9].

Az érintett terület elektronmikroszkópos vizsgálatával a fotoreceptorok lamelláinak fragmentációja, a belső szegment mitokondriumainak duzzadása, a külső szegmentben örvényszerúen összecsapzott membrántestecskék és piknotikus sejtmagok figyelhetők meg. A retinalis pigmentepithelium-sejtek bazálmembránja betüremkedik, a sima felszínú endoplazmatikus retikulum (SER) és a Golgi-apparátusok megduzzadnak, a lipofuscin és melanofuscin granulumok elektrondenzebbé válnak [10]. A károsodást követően körülbelül két nappal a subretinalis térben makrofágok jelennek meg, melyek a külsőbb rétegekre vándorolva fagocitálják a melanosomákat és a sejtes törmeléket [11]. Ennek következtében látható a fundusfotón az általunk is megfigyelt sárgás, az OCTfelvételeken pedig a pigmentepitheliumot és a fotoreceptorok külső szegmensét érintő pontszerü, hiperreflektív laesio.

A károsodás a legtöbb esetben reverzibilis, azonban tartós látásromláshoz és késôi komplikációkhoz is vezethet, mint a metamorphopsia, centralis-paracentralis scotoma $[4,8]$. A korai stádiumban tapasztalt látóélességjavulás jobb prognosztikai faktor, mint a kezdeti károsodás mértéke. Korai gyógyulás esetén teljes restitúció várható 1-6 hónapon belül [12].

A sugárzás okozta retinopathiának nincs specifikus terápiája, a legtöbb károsodás idővel spontán meggyógyul $[4,8]$, szisztémás kortikoszteroid adása azonban bizonyos esetekben - a gyulladásos mediátorok felszaporodása miatt kialakuló reakció szuppressziója révén - elősegítheti, felgyorsíthatja a javulást $[3,12]$. Mindez felhívja a figyelmet a primer prevenció fontosságára, a megfelelő tájékoztatás, oktatás és hatékony fényvédő felszerelések, napszemüvegek, védőfóliás szemüvegek használatára. 
Anyagi támogatás: A közlemény megírása és a kapcsolódó kutatómunka anyagi támogatásban nem részesült.

Szerzői munkamegosztás: M. A., G. E.: Az anamnézis áttekintése, fundusfotó, mikroperimetria- és OCT-felvételek válogatása, irodalomkutatás, a kézirat megírása, végleges változatának elfogadása. N. Z. Zs.: A kézirat revíziója, végleges változatának elfogadása. S. M.: Beteginterakció és diagnózis, szemészeti vizsgálatok, mikroperimetria, fundusfotó és OCT-felvételek készítése és elemzése, a kézirat revíziója, végleges változatának elfogadása. A cikk végleges változatát valamennyi szerző elolvasta és jóváhagyta.

Érdekeltségek: A szerzőknek nincsenek anyagi érdekeltségeik.

\section{Irodalom}

[1] Begaj T, Schaal S. Sunlight and ultraviolet radiation-pertinent retinal implications and current management. Surv Ophthalmol. 2018; 63: 174-192.

[2] Stock RA, Savaris SL, de Lima Filho EC, et al. Solar retinopathy without abnormal exposure: case report. Arq Bras Oftalmol. 2013; 76: 118-120.

[3] Baisakhiya S, Chaudhry M. Acute solar retinopathy. Delhi J Ophthalmol. 2013; 23: 285-287.
[4] Moran S, O'Donoghue E. Solar retinopathy secondary to sungazing. BMJ Case Rep. 2013; 2013: bcr2012008402. Published online 2013 Jan 25. Doi: 10.1136/bcr-2012-008402.

[5] Rosen E. Solar retinitis. Br J Ophthalmol. 1948; 32: 23-35.

[6] Yannuzzi LA, Fisher YL, Krueger A, et al. Solar retinopathy: a photobiological and geophysical analysis. Trans Am Ophthalmol Soc. 1987; 85: 120-158.

[7] American Academy of Ophthalmology. Solar retinopathy. In: Schubert HD. 2013-2014 Basic and Clinical Science Course, Section 12: retina and vitreous. American Academy of Ophthalmology, Singapore, 2013; pp. 332-334.

[8] Khatib N, Knyazer B, Lifshitz T, et al. Acute eclipse retinopathy: a small case series. J Optom. 2014; 7: 225-228.

[9] Comander J, Gardiner M, Loewenstein J. High-resolution optical coherence tomography findings in solar maculopathy and the differential diagnosis of outer retinal holes. Am J Ophthalmol. 2011; 152: 413-419.e6.

[10] Hope-Ross MW, Mahon GJ, Gardiner TA, et al. Ultrastructural findings in solar retinopathy. Eye (Lond). 1993; 7: 29-33.

[11] Ham WT Jr, Ruffolo JJ Jr, Mueller HA, et al. Histologic analysis of photochemical lesions produced in rhesus retina by shortwave-length light. Invest Ophthalmol Vis Sci. 1978; 17: 10291035.

[12] MacFaul PA. Visual prognosis after solar retinopathy. Br J Ophthalmol. 1969; 53: 534-541.

(Schneider Miklós dr., Budapest, Mária u. 39., 1085 e-mail: schneider.miklos@med.semmelweis-univ.hu)

\section{A rendezvények és kongresszusok híranyagának leadása}

a lap megjelenése előtt legalább 40 nappal lehetséges, a 6 hetes nyomdai átfutás miatt. Kérjük megrendelőink szíves megértését.

A híranyagokat a következő címre kérjük: Orvosi Hetilap titkársága: edit.budai@akademiai.hu Akadémiai Kiadó Zrt.

A cikk a Creative Commons Attribution 4.0 International License (https://creativecommons.org/licenses/by/4.0/) feltételei szerint publikált Open Access közlemény, melynek szellemében a cikk bármilyen médiumban szabadon felhasználható, megosztható és újraközölhető, feltéve, hogy az eredeti szerző és a közlés helye, illetve a CC License linkje és az esetlegesen végrehajtott módositások feltüntetésre kerülnek. (SID_1) 